\title{
Low plasma C4 concentrations: association with microangiopathy in insulin dependent diabetes
}

\author{
A H BARNETT, C MIJOVIC, J FLETCHER, I CHESNER, B M KULKUSKA-LANGLANDS, \\ R HOLDER, A R BRADWELL
}

\begin{abstract}
Plasma C4 concentrations were measured in insulin dependent diabetics with and without microangiopathy and in controls. The diabetics had significantly lower $\mathrm{C4}$ values than controls $(p<0.001)$, and patients with insulin dependent diabetes and microangiopathy had lower values than those without this complication $(p<0 \cdot 001)$. There was a 7.1-fold increase in the prevalence of complications in the diabetics with low $\mathrm{C} 4$ values. Of 41 diabetics whose rate of albumin excretion was measured, 13 had increased rates and 11 of these had low $\mathrm{C4}$ concentrations.

Low plasma C4 concentration in insulin dependent diabetes is strongly associated with microvascular disease and may identify diabetics with a particular propensity to develop this complication.
\end{abstract}

\section{Introduction}

Although the development of diabetic microangiopathy appears to be strongly related to poor long term metabolic control, ${ }^{12}$ many patients remain relatively free of complications despite

University of Birmingham and East Birmingham Hospital, Birmingham

A H BARNETT, MD, MRCP, senior lecturer and honorary consultant physician, university department of medicine

C MIJOVIC, BSC, research associate, university department of immunology

J FLETCHER, MRCP, research fellow, university department of medicine

I CHESNER, MRCP, lecturer and honorary senior registrar, university department of medicine

B M KULKUSKA-LANGLANDS, PHD, research associate

A R BRADWELL, FRCP, senior lecturer in immunology and honorary consultant immunologist

Department of Statistics, University of Birmingham, Birmingham B15 2TG

R HOLDER, BSC, lecturer

Correspondence to: Dr A H Barnett, East Birmingham Hospital, Bordesley Green East, Birmingham B9 5ST. inadequate control while others develop problems within a few years after diagnosis. Probably genetic factors also influence the predisposition to complications. ${ }^{3}{ }^{4}$ Controversy surrounds the possible influence of the HLA system, ${ }^{56}$ but support for an immunological basis for microangiopathy comes from studies showing raised values of circulating immune complexes? and insulin binding capacity ${ }^{8}$ in retinopathy and linear deposition of IgG on the glomerular basement membrane in nephropathy. ${ }^{9}$

Recently about one quarter of insulin dependent diabetics have been shown to have low plasma concentrations of the fourth component of complement (C4) irrespective of age and duration of disease. ${ }^{1011}$ This might be due to either complement consumption or phenotypic variation, the latter having been described. ${ }^{12}$ There is a close correlation in C4 values between identical cotwins, even when discordant for diabetes, which suggests that a low $\mathrm{C} 4$ value is inherited. ${ }^{11}$ Plasma C4 is coded for by two separate loci, ${ }^{13}$ each with several variants resulting in a polymorphic system with the possibility of many different phenotypes. ${ }^{14}$ In some people there is deficient expression of the gene, giving rise to low plasma concentrations of the protein. ${ }^{13}$ We have studied the relation of plasma $\mathrm{C} 4$ concentrations in an unselected group of insulin dependent diabetics and their nondiabetic relatives to the prevalence of microangiopathy.

\section{Subjects and methods}

Group 1 comprised 97 insulin dependent diabetics presenting consecutively at a diabetic clinic. Ages ranged from 16 to 54 years (mean 29 (SD 11)) and durations of diabetes from two to 38 years (mean 12 (SD 8)). All subjects had been diagnosed before 30 years of age, were prone to ketosis, and had been taking insulin since diagnosis. Seventy two subjects had no evidence of microangiopathy and eight had mild background retinopathy but no proteinuria on clinic stick testing. Seventeen subjects had severe microvascular complications: 11 had proliferative retinopathy alone, three proliferative retinopathy and persistent proteinuria, and three background retinopathy (haemorrhages and exudates) and persistent proteinuria.

Group 2 comprised 47 non-diabetics and 10 non-insulin dependent diabetics, including one with proliferative retinopathy. The nondiabetics were selected consecutively from a general medical outpatient clinic and none had evidence of autoimmune disease or a family history of diabetes. Since there was no statistically signisicant difference in $\mathrm{C} 4$ concentrations between the non-diabetics and non- 
insulin dependent diabetics (confirmed with larger numbers elsewhere $)^{11}$ they were analysed as a single group. Their ages ranged from 15 to 57 years (mean 37 (SD 12)). In addition, a further 10 noninsulin dependent diabetics with severe complications (same criteria as in group 1) were studied.

Group 3 (relatives)-The first 14 of the 26 insulin dependent diabetics with low $\mathrm{C} 4$ concentrations were selected for family studies. Twelve of these subjects gave names of close relatives who lived locally and who were not diabetic. Thirty three first degree relatives and three first cousins were studied. None had clinical evidence of autoimmune disease.

Blood samples were taken into edetic acid and the plasma stored at $-70^{\circ} \mathrm{C}$. $\mathrm{C} 4$ concentrations were measured by radial immunodiffusion (assay precision 6\%, Serotec Ltd, Oxford). Repeat samples were obtained for most of the insulin dependent diabetics and the mean concentration used.

The following two groups were also selected for further studies. (a) Eight randomly selected insulin dependent diabetics with low C4 values (including three with severe complications) and six insulin dependent diabetics (plus one non-insulin dependent diabetic) with normal C4 values were studied for evidence of complement activation. $\mathrm{CH}_{50}$ and functional $\mathrm{C} 4$ tests were carried out as well as $\mathrm{C} 2$ radial immunodiffusion assays. ${ }^{15}$ (b) Forty one of the 97 insulin dependent diabetics (duration of diabetes five years or more) also had a two hour resting urine collection for albumin excretion carried out on two separate occasions five weeks apart, each subject drinking $500 \mathrm{ml}$ water over the first hour. Albumin excretion was measured by single radial immunodiffusion. ${ }^{16}$ Mean value in an age matched, non-diabetic control group was $8 \cdot 1$ (SD $6 \cdot 3) \mu \mathrm{g} / \mathrm{min}$, and the precision (interassay coefficient of variation) $6 \%$. Values greater than 2 SDs above the mean were taken as abnormal.

The data were analysed using two non-parametric statistical tests. The following comparisons were made: (1) all insulin dependent diabetics (with and without complications) $v$ controls; (2) insulin dependent diabetics with complications $v$ controls; (3) insulin dependent diabetics without complications $v$ controls; (4) insulin dependent diabetics with complications $v$ insulin dependent diabetics without complications.

The Kolmogorov-Smirnov test was applied to see if there was a difference in the distribution of plasma $\mathrm{C} 4$ concentrations of each group. The Mann-Whitney $U$ test was then applied to establish whether the difference was in the median values of each group. A $t$ test was done to see if an observed correlation coefficient was significant for activation studies.

Relative risk (RR) for microangiopathy ${ }^{17}$ was calculated using the formula $\mathrm{RR}=(a d / b c)$, where $a$ represents the number of insulin dependent diabetics with complications and low $\mathrm{C} 4$ values, $b$ represents the number of insulin dependent diabetics with complications but normal $\mathrm{C} 4$ values, $c$ represents the number of insulin dependent diabetics without complications but with low $\mathrm{C} 4$ values, and $d$ represents the number of insulin dependent diabetics without complications and with normal $\mathrm{C} 4$ values.

\section{Results}

There was a highly significant difference in distribution and median values of $\mathrm{C} 4$ concentrations among the various groups (figure; table I).

Given that the groups had significantly different median values of plasma $\mathrm{C} 4$ and no control subject had a value below $0.24 \mathrm{~g} / 1$, concentrations of $0.23 \mathrm{~g} / 1$ or less were defined as low. Overall, of 26 subjects with low $\mathrm{C} 4$ values, $14(54 \%)$ had microvascular disease, 10 with severe and four with mild complications. Two subjects with severe and two with

TABLE I-Comparison of distribution and medians of plasma C4 concentrations

\begin{tabular}{|c|c|c|}
\hline & \multicolumn{2}{|c|}{ Level of significance* } \\
\hline & $\begin{array}{c}\text { Kolmogorov- } \\
\text { Smirnov } \\
\text { test }\end{array}$ & $\underset{\text { U test }}{\text { Mann-Whitney }}$ \\
\hline \multirow{4}{*}{$\begin{array}{l}\text { All insulin dependent diabetics } v \text { controls } \\
\text { Patients with insulin dependent diabetes and } \\
\text { microangiopathy } v \text { controls } \\
\text { Patients with uncomplicated insulin dependent } \\
\text { diabetes } v \text { controls } \\
\text { Patients with insulin dependent diabetes and } \\
\text { microangiopathy } v \text { patients with uncomplicated } \\
\text { insulin dependent diabetes }\end{array}$} & $\mathrm{p}<0.005$ & $\mathrm{p}<0.001$ \\
\hline & $\mathrm{p}<0.001$ & $\mathrm{p}<0.001$ \\
\hline & $\mathrm{p}<0 \cdot 1$ & $\mathrm{p}<0.001$ \\
\hline & $\mathrm{p}<0.025$ & $\mathrm{p}<0.001$ \\
\hline
\end{tabular}

*Kolmogorov-Smirnov test describes difference in distribution between groups and Mann-Whitney U test difference in medians between groups. mild complications had been diagnosed only within the past eight years. The relative risk of subjects with low $\mathrm{C} 4$ concentrations developing severe microangiopathy was $7 \cdot 1$ and of developing any microangiopathy 6.3. Twelve of the 72 insulin dependent diabetics without complications had low $\mathrm{C} 4$ concentrations, but nine of them had been diagnosed only within the past seven years and were therefore unlikely to have developed evidence of microangiopathy. Three out of five tested in this group of 12 in whom albuminuria was measured had increased excretion rates (range $21-80 \mu \mathrm{g} / \mathrm{min}$ ), including one patient with a duration of diabetes of 29 years. Of the 41 insulin dependent diabetics in whom albuminuria was measured, 13 had increased excretion rates (range 21-190 $\mu \mathrm{g} / \mathrm{min}$; mean 51 (SEM 13) $\mu \mathrm{g} / \mathrm{min}$ ); of these, 11 also had low plasma C4 concentrations.

None of the 11 non-insulin dependent diabetics with severe complications had low C4 values (figure).

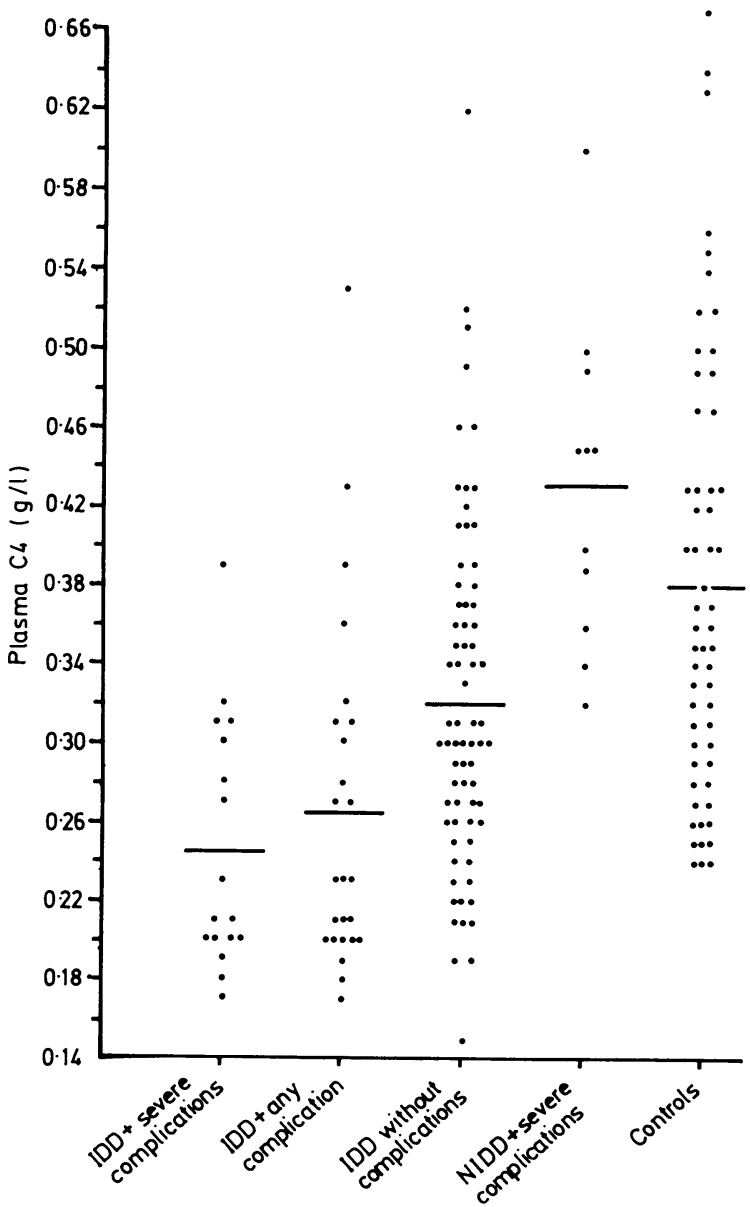

Plasma C4 concentrations in various groups of insulin dependent (IDD), non-insulin dependent (NIDD), and control subjects. Bars are median values.

Of the 36 non-diabetic relatives of insulin dependent diabetics with plasma C4 concentrations of $0.23 \mathrm{~g} / 1$ or less, $9(25 \%)$ also had low values-four out of 15 parents, three siblings, one child, and one first cousin.

Table II shows the interrelations of the various complement components measured. The results indicate that low $\mathrm{C} 4$ concentrations as measured immunologically correlated with functional $\mathrm{C} 4$ values. Overall complement function as measured by $\mathrm{CH}_{50}$ correlated with $\mathrm{C} 2, \mathrm{C} 3$, and $\mathrm{C} 4$ concentrations.

\section{Discussion}

This study confirms other reports that about a quarter of insulin dependent diabetics have low plasma C4 concentrations $^{1011}$ and, in addition, identifies a strong association with microangiopathy. Patients with microangiopathy had a different distribution of $\mathrm{C} 4$ values not only from controls but also from insulin dependent diabetics without such complications. The 
association with low $\mathrm{C} 4$ value was further emphasised by the fact that many insulin dependent diabetics with a low $\mathrm{C} 4$ value but without clinical evidence of complications already showed an increased rate of albumin excretion, which is a predictor for diabetic nephropathy. ${ }^{18}$ Most subjects with a low C4 value and no microangiopathy had been diagnosed only within the past seven years and would not normally have been expected to develop complications until later, and half of those tested already showed increased albumin excretion.

The explanation for this association is not clear, but one possibility is the relation of the $\mathrm{C} 4$ gene to the major histocompatibility complex. Insulin dependent diabetes is associated with various HLA haplotypes including HLA-B8, B15, DR3, and DR4, and genes controlling $\mathrm{C} 4$ are on the same chromosome

TABLE II-Interrelation of complement test results in 14 diabetic patient

\begin{tabular}{|c|c|c|c|}
\hline & & $\mathbf{R}$ & p \\
\hline $\begin{array}{l}\mathrm{C} 2 v \\
\mathrm{C} 2 \\
\mathrm{C} 2 \\
\mathrm{C} 2 \\
\mathrm{C}\end{array}$ & $\begin{array}{l}\mathrm{C} 3 \\
\mathrm{C4} \\
\mathrm{CH}^{*} \\
\mathrm{CH}_{50}\end{array}$ & $\begin{array}{l}0.77 \\
0.47 \\
0.56 \\
0.74\end{array}$ & $\begin{array}{l}<0.001 \\
\text { NS } \\
<0.05 \\
<0.01\end{array}$ \\
\hline $\begin{array}{l}\text { C3 } v \\
\text { C3 } v \\
\text { C3 } v\end{array}$ & $\begin{array}{l}\mathrm{C} 4 \\
\mathrm{C} 4 \mathrm{f} \\
\mathrm{CH}_{50}\end{array}$ & $\begin{array}{l}0.48 \\
0.6 \\
0.76\end{array}$ & $\begin{array}{l}\text { NS } \\
<0.02 \\
<0.001\end{array}$ \\
\hline $\begin{array}{l}\text { C4 } v \\
\text { C4 } v\end{array}$ & $\begin{array}{l}\mathrm{C}_{4} \mathrm{f} \\
\mathrm{CH}_{50}\end{array}$ & $\begin{array}{l}0.92 \\
0.79\end{array}$ & $\begin{array}{l}<0.001 \\
<0.001\end{array}$ \\
\hline $\mathrm{C} 4 \mathrm{f} v$ & $\mathrm{CH}_{50}$ & $0 \cdot 81$ & $<0.001$ \\
\hline
\end{tabular}

NS = Not significant

$*_{\mathrm{f}}=$ Functional assay.

as the HLA genes. ${ }^{19}$ There have been isolated reports of an association between HLA-B8 and nephropathy ${ }^{20}$ and between HLA-B15 ${ }^{21}$ and DR4 ${ }^{22}$ and severe retinopathy, although others have found no association at all. ${ }^{5623-26}$ Indeed, recent reviews conclude that there is little evidence to implicate the HLA complex in the aetiology of microangiopathy.$^{6}{ }^{27}$

Another possibility is that the $\mathrm{C} 4$ gene products might be implicated in the pathogenesis of microangiopathy. Deficient expression of $\mathrm{C} 4$ might lead to failure of clearance of immune complexes resulting in local damage to blood vessel walls.? The C4 produced might also be functionally defective or be consumed. Our studies of the correlation relations between the individual complement proteins suggest activation, but the results are not conclusive. More data and determination of phenotypes should allow this to be assessed.

Studies of identical twins ${ }^{11}$ and our own family data suggest that a low $\mathrm{C} 4$ concentration in insulin dependent diabetes might be inherited. This implies that a low $\mathrm{C} 4$ value is due to abnormal phenotypic expression. The relation between $\mathrm{C} 4$ phenotypes and microangiopathy is being evaluated. Since seven subjects with severe complications (and all of the non-insulin dependent diabetics with complications) had normal C4 values other factors must also play a part.

We conclude that a low plasma C4 concentration is significantly associated with diabetic microangiopathy and might be a predictor of a subgroup of insulin dependent diabetics who have a particular propensity to develop severe microvascular disease.

We thank the West Midlands Regional Research Committee, the British Diabetic Association, and Nordisk UK for financial support, and Professor R Hoffenberg for critical appraisal of the manuscript.

\section{References}

1 Tchobroutsky G. Relation of diabetic control to development of microvascular complications. Diabetologia 1978;1:143-52.

itus and its degenerative complications: a prospective study of 4400 patients observed between 1947 and 1973. Diabetes Care 1978

3 Pyke DA, Tattersall RB. Diabetic retinopathy in identical twins. Diabetes 1973;
4 Leslie RD, Pyke DA. Diabetic retinopathy in identical twins. Diabetes 1982;31:

19-21.
Cove DH, Walker JM, Mackintosh P, Wells L, Wright AD. Are HLA types or BF alleles markers for diabetic retinopathy ? Diabetologia 1980;19:402

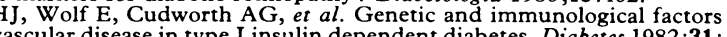
(1982;31:

7 Andreani D. Malignant microangiopathy. Diabetologiz 1980;18:255. Anderson DD. Anti-insulin antibodies and late diabetic complications. Acta Endocrinol (Copenh) 1976;83:329-40.

Westberg NG, Michael AF. Immunohistopathology of diabetic glomerulo-

10 Bertrams J, Hintzen U, Schlicht V, Schoeps S. C4: another marker for type I diabetes. Lancet 1982 ; i: 41

11 Vergani D, Johnston C, B-Abdullah N, Barnett AH. Low serum C4 concentrations: an inherited predisposition to insulin dependent diabetes? $\mathrm{Br} \mathrm{Med} \mathcal{f}$

2 McCluskey J, McCann VJ, Kay PH, et al. HLA and complement allotypes in type 1 (insulin-dependent) diabetes. Diabetologia 1983;24:162-5.

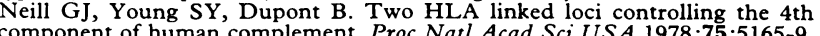
component of human complement. Proc Natl Acad Sci USA 1978;75:5165-9. went of human CA. Inherited structure polymorphism of the fourth compo-

15 Lachmann PJ, Hobart MJ. Immunochemistry-complement technology. Reference handbook of experimental immunology. Vol 1. Oxford: Blackwell Scientific, 1978:5A.1-23.

16 Mancini G, Carbonara AO, Heremans JF. Immunochemical quantitation of antigens by single radial immunodiffusion. Immunochemistry 1965;2:235.

17 Schwartz BD. The human major histocompatibility HLA complex. In: Stites DP, Stobo JD, Fundenberg HH, Wells JV, eds. Basic and clinical immunology. 4th ed. California: Lange Medical Publications, 1982:52-65.

18 Viberti GC, Hill RD, Jarrett RJ, Argyropoulos A, Mahmud U, Keen H. Microalbuminuria as a predictor of clinical nephropathy in insulin dependent

19 Rittner C, Bertrams J. On the significance of C2, C4 and factor B polymorphism

in disease. Hum Genet 1981;56:47.
20 Barbosa J, Noreen H, Emme L, et al. Histocompatibility (HLA) antigens and diabetic microangiopathy. Tissue Antigens 1976;7:233-7.

21 Barbosa J, Ramsay RC, Knobloch WH, Cantrill HL, Noreen H, King R. Histocompatibility antigen frequencies in diabetic retinopathy. Am $\mathcal{J}$ Ophthalmol 1980;90:148-53.

22 Dornan TL, Ting A, McPherson CK, et al. Genetic susceptibility to the development of retinopathy in insulin dependent diabetics. Diabetes 1982;31:226-31 23 Jervell J, Solheim B. HLA-antigens in long-standing insulin dependent diabete with terminal nephropathy and retinopathy with and without loss of vision.
Diabetologia 1979;17:391.

Deckert T, Egeberg J, Frimodt-Moller C, Sander E, Svejgaard A. Basement membrane thickness, insulin antibodies and HLA-antigens in long-standing 1979;17:91-6.

25 Moller E, Persson B, Sterky G. HLA phenotypes and diabetic retinopathy Diabetologia 1978;14:155-8

26 Cudworth AG. Current concepts of aetiology: type I (insulin dependent) diabetes mellitus. In: Bellingham G, ed. Advanced medicine. Vol 16. Tunbridge Wells: Pitman Medical, 1980:123-35.

27 DiMariou U, Iavicoli $M$, Andreani $D$. Immunological aspects of diabetic microangiopathy. In: Andreani D, Federlin KF, DiMario U, Hedging LG, eds Immunology in diabetes. London and Edinburgh: Kimpton Medical Publica-

(Accepted 31 fuly 1984)

\section{ONE HUNDRED YEARS AGO}

A very regrettable case of assault by an infuriated husband, acting under a wholly groundless impression of grievance, on a medical practitioner who had attended the assailant's wife in her confinement, and afterwards received a present from her, again calls attention to the extremely perilous position in which medical men are often unavoidably placed. In this instance the present, a ring, appears to have been sent anonymously, and the recipient had no notion from whom it came. It was, however, it seems, sent without the husband's knowledge, and he not only resented the fact, but, after demanding the return of the ring (which was very properly sent back when demanded), waylaid and assaulted the medical man. It was inevitable that the case should come into court, and Dr. Howell of St. John's Wood has, to the entire satisfaction of the magistrate by whom the matter was heard, vindicated his character, and cleared his reputation from a serious charge. There was abundant evidence of misconception on the part of the husband, and a great presumption of actual delusion on the part of the wife. The disagreeable business is well ended; but, while it passes out of memory, let us again urge, with all the earnestness of which we are capable, the need and importance-vital importance often-of avoiding friendly relations with female patients. We are strongly of opinion that the more strictly and exclusively professional the intercourse of medical men and female patients, the better for all parties. We would even go so far as to insist on the prudence of observing even punctilious etiquette, and the restriction of all intercourse to purely medical directions and remarks, so far as may be compatible with the requirements of perfect courtesy. It is impossible to be too careful, and difficult to be careful enough. (British Medical fournal 1884;ii:1026.) 